\title{
Analysis of Pupils' Higher and Lower Order Thinking Skills in Traffic Education
}

\author{
Monika Valentová ${ }^{1}$, Peter Brečka ${ }^{1}$, Ivana Tureková ${ }^{1}$ \\ ${ }^{1}$ Department of Technology and Information Technologies, Faculty of Education, \\ Constantine the Philosopher University in Nitra, Dražovská cesta 4, 94974 Nitra, Slovakia
}

\begin{abstract}
The effectiveness of education process from teachers' perspective, as well as application of teaching strategies for enhancing Higher Order Thinking Skills (HOTS), is becoming an increasingly frequent subject of discussion across various fields. Bloom's taxonomy is known as the classification of educational goals. This has become the groundwork for many educators worldwide, who are using it to design activities for developing HOTS. This preliminary casestudy analyses knowledge of traffic and road safety within pupils, as well as their level of thinking skills in this field with emphasis on analytical skills and risk assessment in traffic. A didactic test was assembled to examine the level of thinking of $4^{\text {th }}$ grade primary school pupils. The results showed that pupils' level of knowledge in the field is age-adequate; however, in application of HOTS, as well as risk assessment, there is room for improvement.
\end{abstract}

Keywords - road safety, educational, pupils, primary school, HOTS, LOTS.

\section{Introduction}

Road safety has been the subject of educational authorities [1] and of persistent international focus due to the widespread economic and social consequences of road accidents, especially fatalities, among young people [2]. Statistical analyses of road

DOI: 10.18421/TEM102-46

https://doi.org/10.18421/TEM102-46

Corresponding author: Peter Brečka,

Department of Technology and Information Technologies, Faculty of Education, Constantine the Philosopher University in Nitra, Nitra, Slovakia.

Email: pbrecka@ukf.sk

Received: 24 March 2021.

Revised: 15 April 2021.

Accepted: 21 April 2021.

Published: 27 May 2021.

(c) BY-Nc-ND(C) 2021 Monika Valentová, Peter Brečka \& Ivana Tureková; published by UIKTEN. This work is licensed under the Creative Commons AttributionNonCommercial-NoDerivs 4.0 License.

The article is published with Open Access at www.temjournal.com accidents have shown that children aged 5 to 14 are the most vulnerable group. Children of this age are at higher risk of injury, especially as pedestrians and cyclists [3]. This has been confirmed by the World Health Organization. WHO included road accidents among the top four most common causes of death in children aged 5 to 14 [4].

The issue of road safety resonates quite intensively in scientific and pedagogical community, too. The purpose of this focus has been the continuous proposal of optimal prevention measures and strategic approaches in this area since 2005. This arises from the joint effort of multiple OECD countries from 2004, according to which Road Safety Education (RSE) will become a priority in schools [5]. RSE has been recognized as the key method of reducing accident rate [6], [7], [8].

An important prerequisite for successful RSE is teaching student's awareness of dangers. According to Alonso [9], knowledge of traffic standards alone does not warrant safe behaviour, it needs to be combined with risk awareness and positive attitude towards road safety. Risk awareness is directly related to risky and dangerous behaviour of children and young people on the road [10].

Thus, it is not enough for pupils to merely learn the rules or remember them. It is necessary for children to know how to apply them in practice and to be able to observe their surroundings, perceive and evaluate the risks, and adapt their behaviour. Inability to scan the surrounding environment effectively and actively for information on traffic, inconsistent behaviour, and insufficiently developed risk perception are the most frequent factors boosting the risk of accidents in traffic among children [11].

Education should, therefore, lead to adjustments in pupils' behaviour on the road [8], [12]. It is necessary for them to develop thinking skills beyond memorization that will lead them to identify hazards and behave more safely.

\section{Education Towards Safety}

In Slovakia, education is one of the primary measures to prevent against injuries on the road among children and young people. Therefore, an important milestone in the context of increasing 
safety of children on the roads is the Decree of the Government of the Slovak Republic No. 798, which lays out the strategy for increasing road safety in the Slovak Republic for the years 2011 to 2020 [13]. The Ministry of Education, Science, Research and Sports of the Slovak Republic, in accordance with the above-mentioned strategy, performs tasks in the field of continuous traffic and road safety education in schools. In this context, traffic education was included in curriculum for all grades of primary schools, i.e., from the $1^{\text {st }}$ to the $9^{\text {th }}$ grade.

Traffic education appears to be the best instrument for traffic accident prevention [14]. It is a process that aims to shape and transform young people's attitudes towards collective and healthy life and to strive to improve their quality of life through responsible behaviour [15].

Pupils at primary education level get acquainted with the content of traffic education and its goals by implementing certain number of these elements in other subjects, such as: technical education, science, geography.

The content of this course should prepare pupils for safe movement in road traffic - both pedestrians and cyclists. The role of the teacher is to apply teaching strategies to meet the following goals within RSE:

- to understand the function of transport as a managed system defined by generally binding legal regulations;

- to form moral consciousness and behaviour in terms of moral and legal responsibility when walking on foot or cycling in road traffic;

- to acquire the principles of safe behaviour in road traffic according to generally binding legal regulations for pedestrians, cyclists and car passengers;

- to teach pupils to observe their surroundings, evaluate the situation from safety perspective and to apply habits of safe behaviour in road traffic in practical life;

- to help master the techniques of walking and cycling;

- to help master the basic tactical elements of walking and bicycle riding in road traffic;

- to help understand the importance of vehicle maintenance for safety in road traffic and practically master the basic tasks of bicycle maintenance;

- to help children understand the importance of technical transport conditions and equipment affecting road safety [16].

The enhancement of the cognitive domain is very important in the field of road safety. This is also evidenced by the results of a study [10] which showed that pupils with insufficient knowledge about traffic signals and standards were more likely to take risks in their behaviour in traffic.

Nevertheless, acquiring knowledge alone is not sufficient either. Another study suggests that increasing road safety knowledge may not be explicitly reflected in improvement in pupils' behaviour in practical traffic situations [17]. One of the pillars of RSE is the belief that pupils need to understand traffic rules and situations [6], [18].

There is ample evidence that theoretical knowledge is only effective if pupils are provided practical opportunities to identify [19] and practically apply it.

This is also included among the key competencies of the State Educational Programme of the SR, towards which the teacher and students work as part of RSE. We have tried verifying whether this is the case through a pilot study conducted with primary school pupils.

\section{Methodology}

The objective of this pilot research was to determine the level of knowledge possessed by pupils in traffic education. Testing was performed in 2019 in five primary schools across the Slovak Republic. 4th grade primary school pupils participated in the study. The research sample consisted of a total of 85 pupils.

To research the current level of pupils' knowledge in traffic education, a didactic test was designed. Questions were based on the goals arising from the RSE curriculum and the principles of B.S. Bloom's taxonomy. Taxonomy refers to 6 levels of learning goals that teachers set for students [20], ranked from the lowest thinking skills to the highest.

The individual levels overlap and are interconnected, i.e., achieving each HOTS requires achieving a previous lower one [21].

LOTS include remembering, understanding, and applying. HOTS are reflected at the highest levels in Bloom's taxonomy [22]: analysing [23], [24], evaluating (assessment, argumentation) [25], [26] and creating (synthesis of conclusions, arguments) [27], [28] (Figure 1).

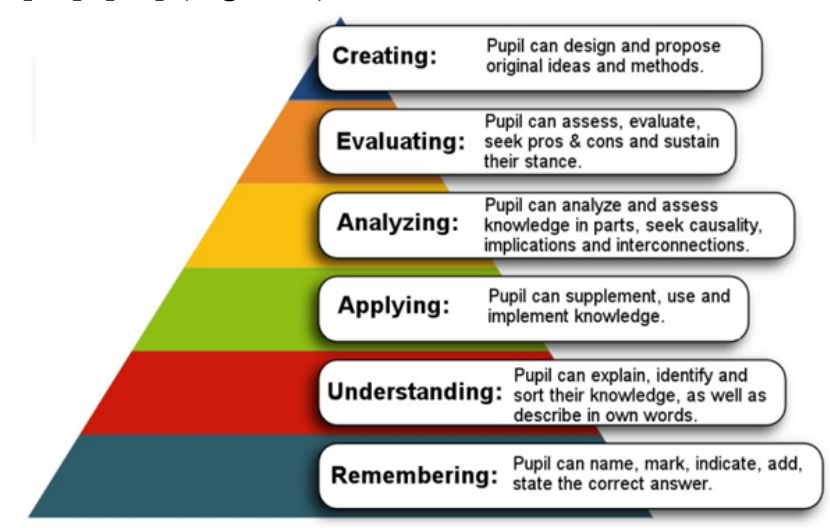

Figure 1. Bloom's Taxonomy model 
The didactic test consisted of 18 tasks aimed at different levels of thinking in accordance with the principles of B.S. Bloom's taxonomy:

- In the tasks aimed at remembering (No. 1, 5, 8, $11,12,14,16)$ we tested pupils' ability to repeat the knowledge, name, mark, fill in missing information, choose correct answer, e.g.: name road signs, mark colours at traffic lights with meaning, etc.

- In the tasks aimed at understanding (No. 2, 3, 7, 15) we researched pupils' ability to interpret the acquired knowledge in various ways, for example: explain, identify, describe in a different way, describe it in their own words, sort, e.g.: describe how a pedestrian should move on the road if there is no sidewalk nearby, explain the importance of the cyclist's mandatory equipment, etc.

- In the tasks aimed at applying (No. 9) we investigated pupils' ability to use the acquired knowledge in problem resolution, i.e., whether they know how to supply, implement information, for example: draw in missing mandatory equipment for pedestrians in case of reduced visibility.

- In the tasks aimed at analysing (No. 4, 6, 10, 13, $17,18)$ we tested pupils' ability to seek causes, connections, and consequences, analyse situations based on knowledge acquired in parts, assess, and analyze information or situations in parts, determine the relationship and links between these parts and possible consequences. Since in analysis the pupils were expected to be able to argue and judge, analysing often overlaps with the level of evaluating. Therefore, this level was also included and assessed based on the results from questions no. 4, 6, 10,12, 17, and 18. We tried to determine whether pupils are able to evaluate knowledge, assess, seek pros \& cons and most of all, argue, for example: assess whether running out on the road behind a bus or other obstacle is safe and sustain your claim, assess whether the pupil's behaviour (pictured) when getting in or out of the car is safe, etc.

- Pilot testing did not include tasks aimed at creating.

Weighted scoring was used to evaluate the test, meaning, the tasks were scored depending on their focus. The maximum number of points that pupils could acquire for the correct completion of the entire test was 42 points.

\section{Results}

Overview of overall test results is presented in Figure 2.

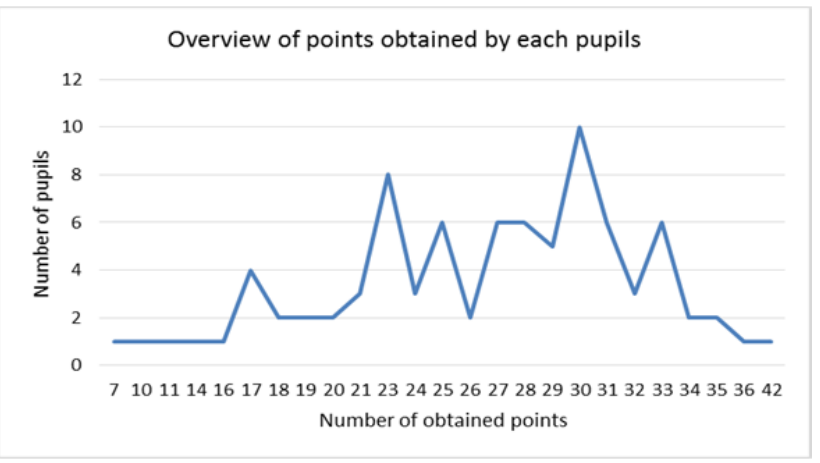

Figure 2. Overview of points obtained by each pupil

On average, the pupils scored 26 points on the test. The maximum number of points (42) was obtained by one pupil. The most highly represented group were pupils who obtained 30 points. Thus, the graphical representation of obtained points shows that the highest success rate ranged from 23 to 31 obtained points.

Among positive findings is the fact that in tasks aimed at LOTS (memorization, comprehension), students achieved very good to excellent scores in the range of 50\% - 90\% (Figure 3, 4). Students possess knowledge on the basic rules of cycling, the mandatory equipment for cyclist, rules for pedestrians and know how to behave when approaching a vehicle with the right of way. Pupils also have a good knowledge of contact information for emergency services.

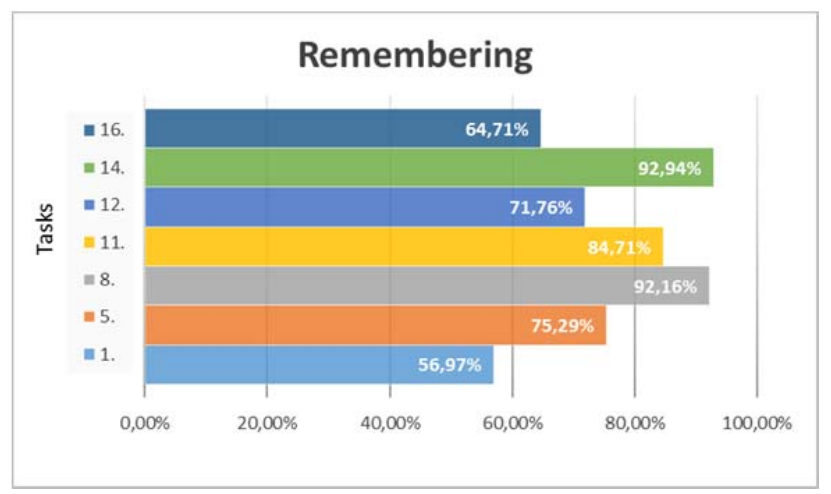

Figure 3. Scores obtained in tasks aimed at remembering

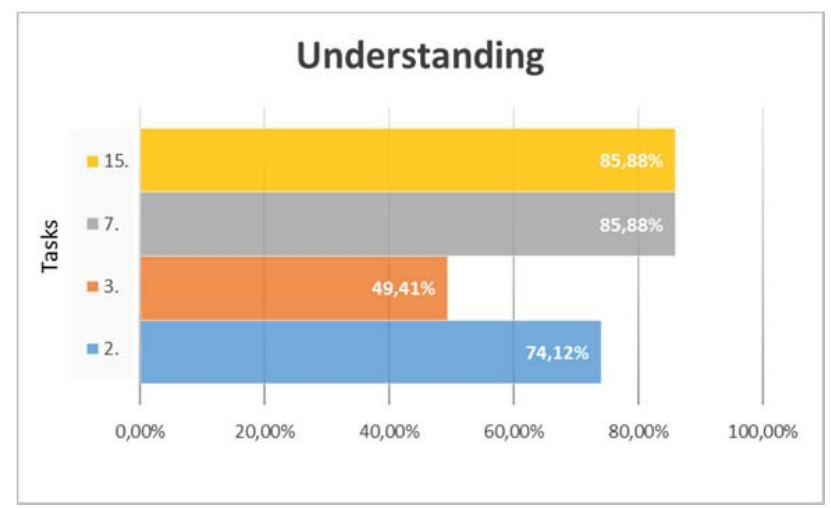

Figure 4. Scores obtained in tasks aimed at understanding 
The obtained results show that teachers provide sufficient support to pupil in acquiring road safety knowledge and select appropriate teaching strategies that enhance awareness. However, it would be incorrect to assume that memorised information will suffice for the pupils to behave safely and to be able to assess risks. This has also been confirmed by the study of Zeedyk et al. [17], which shows that both teachers and parents should distinguish between pupils' knowledge of road safety and their safe behaviour, as they may mistakenly assume that pupil who possess more knowledge will behave with more caution on the road.

This, according to Bloom, highlights the need to create space for enhancing HOTS in students, as they will better assess dangerous situations, understand the environment in which they operate and will, also, improve in decision making. Therefore, we investigated whether teachers apply teaching strategies to develop HOTS in the context of RSE.

We were interested in pupils' ability to recognise, analyse and evaluate dangerous behaviour in road traffic and the ability to apply acquired knowledge in practice, as this competency is also imparted in the educational standards. We investigated this through open tasks, in which pupils had to assess or analyse a dangerous situation or behaviour of a person in the picture and justify why the situation is dangerous, or what may occur as a result of careless behaviour.

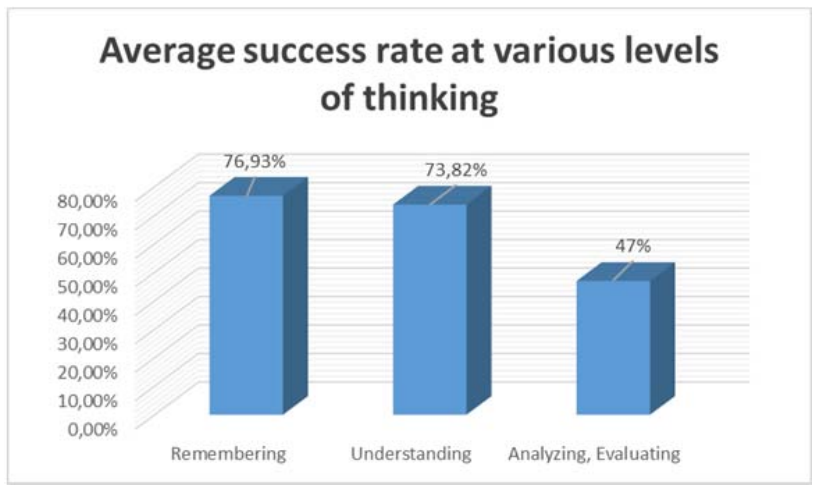

Figure 5. Average success rate at various levels of thinking

It can be deduced, from the graphical result representation in Figure 5 that the principal issue we face in this area is that, despite sufficient knowledge in traffic and road safety, pupils lack the ability to evaluate and assess the severity of certain situations or actions that may lead to injury or traffic accident.

The results show that while in tasks aimed at LOTS the average success rate ranged from $50 \%$ to $90 \%$, whereas in tasks focusing on HOTS success was approx. $50 \%$.

To summarize, despite good knowledge of traffic rules and road safety, pupils were unable to practically apply the gained information or actively analyse or evaluate risks.

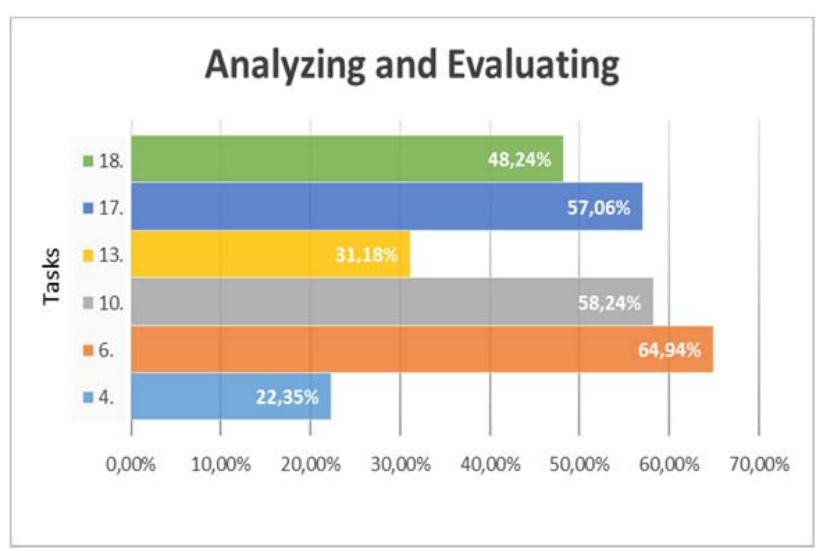

Figure 6. Scores obtained in tasks aimed at analysing and evaluating

In all tasks aimed at HOTS, we noticed considerable limitations in pupils, not only in the field of analysis, but also evaluation. Pupils had issues identifying a dangerous situation (pedestrian behaviour in the picture), in which the pedestrian runs out from behind of the bus. They failed to point out that the pedestrian in the picture is not crossing the road correctly, because there is no pedestrian crossing in place and also runs in front of the bus thus the driver in the car preceding the bus notices him late and can potentially represent danger for him.

The analysis also showed that the pupils could not accordingly assess and evaluate the pedestrian's walk on the road, without a pavement. Pedestrian was also walking along the wrong side of the road, yet pupils failed to assess the situation as dangerous. They also failed to identify the dangerous behaviour of a pedestrian on the crossing, who was using their phone or listening to music through headphones.

Despite good knowledge and remembering cyclists' mandatory equipment, pupils had difficulty assessing the cyclist's behaviour in the picture and identifying the missing mandatory equipment. The pupils could not assess the cyclist's behaviour in the illustration as dangerous when they rode their bicycle on the incorrect side of the road and was not wearing a safety helmet.

We also noticed limitations analysing and evaluating the behaviour of a pupil (pictured) who was getting into/out of the car on the side of the road.

\section{Conclusion}

The analysis of pupils' thinking levels in the field of traffic and road safety has demonstrated that although pupils have a good knowledge of traffic education, in tasks aimed at risk assessment and perception of consequences or causes of dangerous situations, they had problems with reasoning and substantiating their claims.

These findings may stem from a number of issues raised by the teachers during the research: 
- Absence of various teaching aids and bicycles for pupils;

- Issues with actual implementation of RSE. As it is not a compulsory subject, teachers often omit RSE in education due to insufficient time or aids;

- At times, RSE is realized as after-school activity which, however, does not involve all students, as it depends on the financial situation of the parents;

- Parents' workload and constant need to rush is also a considerable issue. As a result, parents often drive their children directly in front of the school grounds, thus, pupils have no opportunity to gain practical experience with traffic situations, while at the same time, and parents have no opportunity to remind them of the basic rules of road traffic upon sighting incorrect/hazardous behaviour.

For prevention in education of children and youth we suggest to:

- Apply simulated learning strategies [29]. In this way, students can experience various situations, acquire self-management skills (decision-making and planning) and better understand the importance of traffic rules and dangers in different situations. RSE has to its maximum ability; include practical activity of pupils in real situations. This will provide them with experiential tools to reinforce positive behaviour on the road [30];

- Create a space for discussions with people who have experienced dangerous situations, so that pupils better understand the consequences of not following the rules of the road;

- Apply training in a virtual environment [31].

\section{Acknowledgements}

This contribution was created in the frame of KEGA 014UKF-4/2020 innovative learning e-modules for safety in dual education.

\section{References}

[1]. Papakitsos, E. C., Korakidi, G., Vamvakeros, X., \& Mavrakis, A. (2018). Planning Educational Activities for Learning "Road Safety". Humanities and Social Science Research, 1(2), p43-p43.

[2]. Adanu, E. K., Penmetsa, P., Jones, S., \& Smith, R. (2018). Gendered analysis of fatal crashes among young drivers in Alabama, USA. Safety, 4(3), 29. https://doi.org/10.3390/safety4030029

[3]. Lavoie, M., Burigusa, G., Maurice, P., Hamel, D., \& Turmel, E. (2014). Active and safe transportation of elementary-school students: comparative analysis of the risks of injury associated with children travelling by car, walking and cycling between home and school. Chronic diseases and injuries in Canada, 34(4), 195-202.

[4]. World Health Organization. (2015). Global status report on road safety 2015 . World Health Organization. Retrieved from: https:/www.afro.who.int/sites/default/files/201706/9789241565066 eng.pdf

[5]. Organisation for Economic Co-operation and Development (OECD). (2004). Keeping children safe in traffic. Paris, France: Organisation for Economic Co-operation and Development. Retrieved from: https://www.oecd.org/sti/keepingchildrensafeintraffic. htm [accessed: 17 Febrary 2021].

[6]. Assailly, J. P. (2017). Road safety education: What works?. Patient education and counseling, 100, S24S29.

[7]. Obregón-Biosca, S. A., Betanzo-Quezada, E., Romero-Navarrete, J. A., \& Ríos-Nuñez, M. (2018). Rating road traffic education. Transportation research part F: traffic psychology and behaviour, 56, 33-45.

[8]. Twisk, D. A., Vlakveld, W. P., Commandeur, J. J., Shope, J. T., \& Kok, G. (2014). Five road safety education programmes for young adolescent pedestrians and cyclists: A multi-programme evaluation in a field setting. Accident Analysis \& Prevention, 66, 55-61.

[9]. Alonso, F., Gonzalez-Marin, A., Esteban, C., \& Useche, S. A. (2020). Behavioral health at school: do three competences in road safety education impact the protective road behaviors of Spanish children?. International journal of environmental research and public health, 17(3), 935.

[10]. Alonso, F., Esteban, C., Useche, S., \& Colomer, N. (2018). Effect of road safety education on road risky behaviors of Spanish children and adolescents: findings from a national study. International journal of environmental research and public health, 15(12), 2828 . 
[11]. Riaz, M. S., Cuenen, A., Janssens, D., Brijs, K., \& Wets, G. (2019). Evaluation of a gamified e-learning platform to improve traffic safety among elementary school pupils in Belgium. Personal and Ubiquitous Computing, 23(5), 931-941.

[12]. ROSE 25. (2005). Good Practice Guide On Road Safety Education. Retrieved from: https://pracoreana.com/sites/default/files/rose 25.pdf [accessed: 17 January 2021].

[13]. Ministerstvo školstva Slovenskej republiky. (2007). Dopravná výchova pre 1. - 9. ročník základnej školy nadpredmetové učebné osnovy. Retrieved from: https://www.minedu.sk/dopravna-vychova/ [accessed: 17 January 2021].

[14]. Stojan, M. a kol. (2006). Dopravní výchova pro učitele 1. stupně ZŠ. Brno: Katedra didaktických technologií PdF MU.

[15]. Freitas, CKAC, Rodrigues, MA, Fontes, VS, Barreiro, MDSC, Santos, ACFSD, Lima, SVMA, ... \& Mota, ECH (2020). Risk And Preventive Factors For Traffic Accidents: Analysis Of Children's Perception Using The Edutherapeutic Method. Revista Paulista de Pediatria , 38 .

[16]. National Institute For Education In Slovak Republic. (2020). Dopravná Výchova - Výchova K Bezpečnosti V Cestnej Premávke. Retrieved from: https://www.statpedu.sk/sk/svp/statny-vzdelavaciprogram/svp-druhy-stupen-zs/prierezovetemy/dopravna-vychova-vychova-k-bezpecnosticestnej-premavke/ [accessed: 10 February 2021].

[17]. Zeedyk, M. S., Wallace, L., Carcary, B., Jones, K., \& Larter, K. (2001). Children and road safety: Increasing knowledge does not improve behaviour. British Journal of Educational Psychology, 71(4), 573-594.

[18]. Alonso, F., Esteban, C., Useche, S. A., \& Manso, V. (2016). Analysis of the state and development of road safety education in Spanish higher education institutions. Higher Education Research, 1(1), 10.

[19]. Rothengatter, J. A. (1981). The influence of instructional variables on the effectiveness of traffic education. Accident Analysis \& Prevention, 13(3), 241-253.

[20]. Gogus, A. (2012). Bloom's Taxonomy of Learning Objectives. In: Seel, N. M. (eds) Encyclopedia of the Sciences of Learning. Springer, Boston, MA.
[21]. Krathwohl, D. R. (2002). A revision of Bloom's taxonomy: An overview. Theory into practice, 41(4), 212-218.

[22]. Watson, S. (2019). Higher-order thinking skills (HOTS) in education. Teaching Students to Think Critically. Retrieved from: https://www.thoughtco.com/higher-order-thinkingskills-hots-education-3111297 [accessed: 17 February 2021].

[23]. Facione, P. A. (1990). Critical Thinking: A Statement of Expert Consensus for Purposes of Educational Assessment and Instruction. Research Findings and Recommendations.

[24]. Halpern, D. F. (2001). Assessing the effectiveness of critical thinking instruction. The Journal of General Education, 50(4), 270-286.

[25]. Lipman, M. (1988). Critical Thinking--What Can It Be?. Educational Leadership, 46(1), 38-43.

[26]. Tindal, G., \& Nolet, V. (1995). Curriculum-based measurement in middle and high schools: Critical thinking skills in content areas. Focus on Exceptional Children, 27(7), 1-22.

[27]. Paul, R. (1992). Critical thinking: What, why, and how. New Directions for Community Colleges, 1992(77), 3-24.

[28]. Bloom, B. S. (1956). Taxonomy of educational objectives: The classification of educational goals. Cognitive domain.

[29]. The Northern Territory Government. (2021). Strategies, Teaching and learning strategies. Retrieved from:

https://nt.gov.au/ data/assets/pdf file/0006/380751/ safer-roads-primary-strategies.pdf [accessed: 20 February 2021].

[30]. Trifunović, A., Pešić, D., Čičević, S., \& Antić, B. (2017). The importance of spatial orientation and knowledge of traffic signs for children's traffic safety. Accident Analysis \& Prevention, 102, 81-92.

[31]. Morrongiello, B. A., Corbett, M., Beer, J., \& Koutsoulianos, S. (2018). A pilot randomized controlled trial testing the effectiveness of a pedestrian training program that teaches children where and how to cross the street safely. Journal of pediatric psychology, 43(10), 1147-1159. 